\title{
Effects of Abiotic Elicitors on Expression and Accumulation of Three Candidate Benzophenanthridine Alkaloids in Cultured Greater Celandine Cells
}

\author{
Seyed Mohammad Hashemi ${ }^{1, * \mathbb{D}}$, Mohammad Reza Naghavi ${ }^{2} * \mathbb{D}$, Esmaeil Bakhshandeh ${ }^{3}$, Mehdi Ghorbani ${ }^{2}$, \\ Chanditha Priyanatha ${ }^{1}$ and Peiman Zandi ${ }^{4,5}$ (D)
}

check for

updates

Citation: Hashemi, S.M.; Naghavi, M.R.; Bakhshandeh, E.; Ghorbani, M.; Priyanatha, C.; Zandi, P. Effects of Abiotic Elicitors on Expression and Accumulation of Three Candidate Benzophenanthridine Alkaloids in Cultured Greater Celandine Cells. Molecules 2021, 26, 1395. https:// doi.org/10.3390/molecules26051395

Academic Editor: Marcello Iriti

Received: 15 February 2021

Accepted: 28 February 2021

Published: 5 March 2021

Corrected: 17 August 2022

Publisher's Note: MDPI stays neutral with regard to jurisdictional claims in published maps and institutional affiliations.

Copyright: (c) 2021 by the authors. Licensee MDPI, Basel, Switzerland. This article is an open access article distributed under the terms and conditions of the Creative Commons Attribution (CC BY) license (https:// creativecommons.org/licenses/by/ $4.0 /)$.
1 Department of Plant Agriculture, Ontario Agriculture College, University of Guelph, 50 Stone Road East, Guelph, ON N1G 2W1, Canada; cpriyana@uoguelph.ca

2 Department of Agronomy and Plant Breeding, College of Agriculture and Natural Resources, University of Tehran, Karaj 31587-77871, Iran; mghorbani_90@ut.ac.ir

3 Genetics and Agricultural Biotechnology Institute of Tabarestan, Sari Agricultural Sciences and Natural Resources University, Sari 4818166996, Iran; e.bakhshandeh@sanru.ac.ir

4 Julius Kühn-Institut, Federal Research Centre for Cultivated Plants, Institute for Crop and Soil Sciences, Bundesallee 69, 38116 Braunschweig, Germany; z_rice_b@yahoo.com

5 International Faculty of Applied Technology, Yibin Unversity, Yibin 644000, China

* Correspondence: seyedh@uoguelph.ca (S.M.H.); mnaghavi@ut.ac.ir (M.R.N.)

\begin{abstract}
Efforts to develop the necessary biotechnologies in Greater Celandine (Chelidonium majus L.), a leading plant resource for the development of plant-derived medicines, have been hampered by the lack of knowledge about transcriptome and metabolome regulations of its medicinal components. Therefore, this study aimed to examine the effect of abiotic elicitors, methyl jasmonate (MJ) and salicylic acid (SA), at different time courses $(12,24,48$, and $72 \mathrm{~h})$, on expression and metabolome of key benzophenanthridine alkaloids (BPAs) in an optimized in vitro culture. Gene expression analysis indicated the upregulation of CFS (cheilanthifoline synthase) to 2.62, 4.85, and 7.28 times higher than the control at 12,24, and $48 \mathrm{~h}$ respectively, under MJ elicitation. Besides, MJ upregulated the expression of TNMT (tetrahydroprotoberberine $N$-methyltransferase) to $2.79,4.75$, and 7.21 times at 12,24 , and $48 \mathrm{~h}$ respectively, compared to the control. Investigation of BPAs revealed a significant enhancement in the chelidonine content $(9.86 \mu \mathrm{g} / \mathrm{mg})$ after $72 \mathrm{~h}$ of MJ elicitation. Additionally, sanguinarine content increased to its highest level $(3.42 \mu \mathrm{g} / \mathrm{mg})$ after $24 \mathrm{~h}$ of MJ elicitation; however, no significant enhancement was detected in its content in shorter elicitation time courses. Generally, higher gene expression and BPAs' level was observed through longer elicitation courses (48 and $72 \mathrm{~h}$ ). Our findings take part in improving the understanding of transcription and metabolic regulation of BPAs in cultured Greater Celandine cells.
\end{abstract}

Keywords: benzophenanthridine alkaloids; Chelidonium majus L.; elicitation; secondary metabolites; transcription regulation

\section{Introduction}

Greater Celandine (Chelidonium majus L.) is a biennial/perennial plant native to Europe and North Asia [1]. It is a promising medicinal plant in terms of traditional and modern pharmacology, which covers a range of valuable phytochemicals, most notably anti-cancer chelidonine [2], anti-inflammatory berberine [3], and anti-bacteria sanguinarine [4]. This plant is well-known for its lead in the industry of anti-cancer plant-derived medicines $[5,6]$. Ukrain ${ }^{\mathrm{TM}}$, derived from secondary metabolites (SMs) of Greater Celandine, is extensively accepted as a pharmaceutically active and clinically effective anti-cancer medicine [6]. To produce SMs for medicinal purposes, most plant-based pharmaceutical industries are propagating plants through traditional manners. They are planting them on the 
farm and extracting medicinal components directly from intact plants, which completely depends on the growing location and harvesting season [7].

Plant cell culture, on the other hand, is introduced as a potential alternative to upscale production of SMs in a shorter time and less space than traditional manners [7]. Moreover, a higher level of SMs production of different medicinal plants through cell culture has already been reported [8,9], although the production level of SMs through cell culture is still considerably lower than the intact plant in some cases. Particular substances called "elicitors" are applied as stress agents to boost the SM production in cultured plant cells [10]. Application of these substances to stimulate the production of SMs in plant cells is called "elicitation" and it initiates by an attack on the plant cell, then triggers a cascade of signal transduction pathways and finally leads to enhance expression of related genes and improve SMs accumulation [11,12].

Methyl jasmonate (MJ) and salicylic acid (SA) are two well-known elicitors and pivotal defense signaling molecules that can trigger a stress-response cascade, resulting in improvement of the SMs accumulation [13]. Almost all SM biosynthetic pathways, including benzophenanthridine alkaloids (BPAs), are induced by the application of jasmonates (JA) or endogenous enhancement in JA [14,15]. Accumulation of BPAs has also been improved in cell suspension cultures of Rauvolfia canescens and Eschscholtzia californica, well-known medicinal plants, after elicitation with JA [15]. These elicitors, MJ and SA, also play a crucial role in stimulating the expression of SMs-related genes [16,17]. There are seven reactions in the biosynthetic pathway of BPAs [18] and three of them: CFS (cheilanthifoline synthase), STS (stylopine synthase), and TNMT (tetrahydroprotoberberine N-methyltransferase), are key in the regulation of BPAs $[19,20]$ (Figure 1).

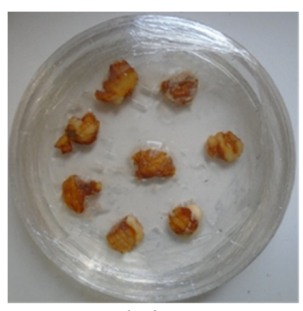

(a)

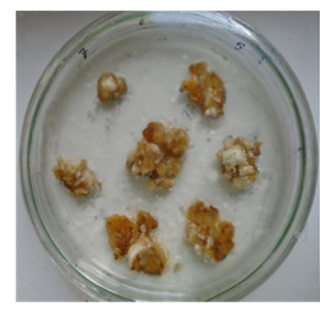

(b)

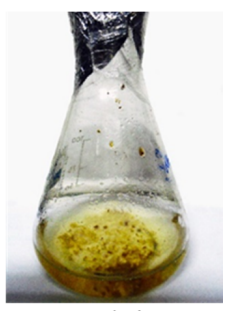

(c)

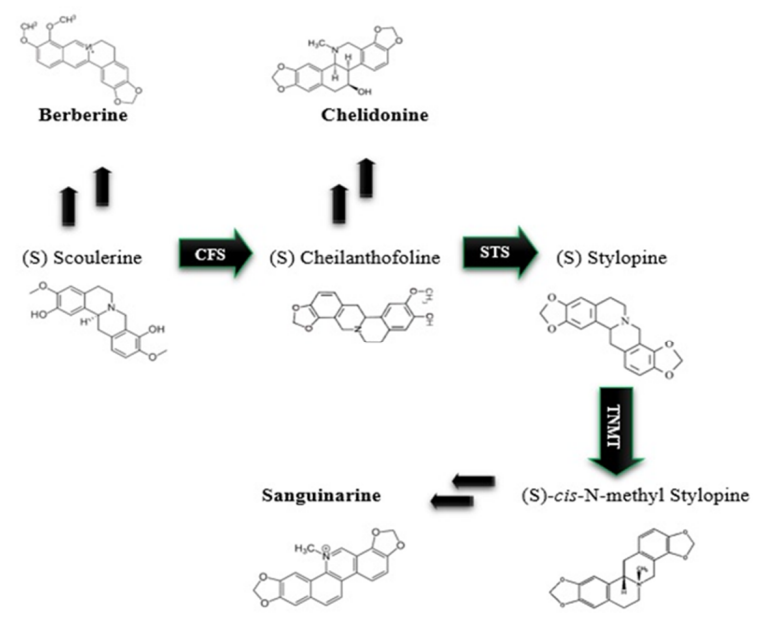

(d)

Figure 1. Callus and cell suspension culture of Greater Celandine. (a) The initiation phase of calli in leaf explants on Murashige and Skoog (MS) medium supplemented with $1 \mathrm{mg} \mathrm{L}^{-1}$ of indole-3acetic acid (IAA) and $0.2 \mathrm{mg} \mathrm{L}^{-1}$ of 6-benzylaminopurine (BAP). (b) Callus culture on MS medium supplemented with $1 \mathrm{mg} \mathrm{L}^{-1}$ IAA and $0.2 \mathrm{mg} \mathrm{L}^{-1}$ BAP. (c) Cell suspension culture of Greater Celandine. (d) The metabolic pathway of benzophenanthridine alkaloids that illustrates the role ofCFS (cheilanthifoline synthase), STS (stylopine synthase), and TNMT (tetrahydroprotoberberine $N$-methyltransferase) enzymes $[19,20]$. 
Previous studies from our laboratory demonstrated that MJ and SA play central roles as abiotic stimulators in improving the accumulation and gene expression of SMs such as morphine, codeine, artemisinin, etc. However, the role of these stimulators in the production and gene expression of BPAs using cell suspension culture of Greater Celandine remains unclear. Consequently, the main objective of this study is to investigate the effect of MJ and SA on the biosynthesis of BPAs and the expression of their related genes at different time courses. Furthermore, the present study also aimed to analyze the role of different tissue sources, media type, auxins, and cytokinins in callus induction of Greater Celandine since callus culture optimization is a prerequisite for the propagation process of cell culture.

\section{Results}

\subsection{Propagation Optimization}

Two types of media, MS (Murashige and Skoog) and B5 (Gamborg B5), three sources of explants (leaf, shoot, and nodal), and four types of plant growth regulators (PGRs), IAA (indole-3-acetic acid), NAA (1-naphthaleneacetic acid), 2,4-D (2,4-dichlorophenoxyacetic acid), and BAP (6-benzylaminopurine), were tested to uncover the most efficient platform for callus induction of Greater Celandine. Figure 2 illustrates the callus induction frequency under different treatments. It was revealed that MS medium is significantly more favorable than B5 medium to produce and propagate a callus. Compared to nodal and shoot tissue, leaf explants, with $59.13 \%$ of callus induction on the MS media, were revealed to be the more favorable tissue source to initiate callus formation (Figure 2a). A closer look at the data indicates that the combination of $1 \mathrm{mg} \mathrm{L}^{-1} \mathrm{IAA}$ and $0.2 \mathrm{mg} \mathrm{L}^{-1}$ BAP on the MS medium for leaf, nodal, and shoot explants with $82 \%, 48 \%$, and $54 \%$ respectively, was more effective than other PGR combinations (Figure 2a). The B5 basal medium supplemented with $0.5 \mathrm{mg} \mathrm{L}^{-1}$ IAA and $0.2 \mathrm{mg} \mathrm{L}^{-1}$ BAP was found to be the most promising platform for shoot explants, with $56 \%$ of callus induction frequency (Figure $2 \mathrm{~b}$ ). For nodal explants, moreover, the highest percentage of callus induction (52\%) was achieved on MS medium supplemented with $0.5 \mathrm{mg} \mathrm{L}^{-1}$ IAA and $0.2 \mathrm{mg} \mathrm{L}^{-1} \mathrm{BAP}$. The highest number of callus initiation was obtained on MS medium supplemented with $1 \mathrm{mg} \mathrm{L}^{-1}$ IAA and $0.2 \mathrm{mg} \mathrm{L}^{-1}$ BAP using leaf as explant, whereas the lowest percentage was detected on MS medium supplemented with $0.5 \mathrm{mg} \mathrm{L}^{-1} \mathrm{NNA}$ and $0.5 \mathrm{mg} \mathrm{L}^{-1}$ BAP using nodal as explant.

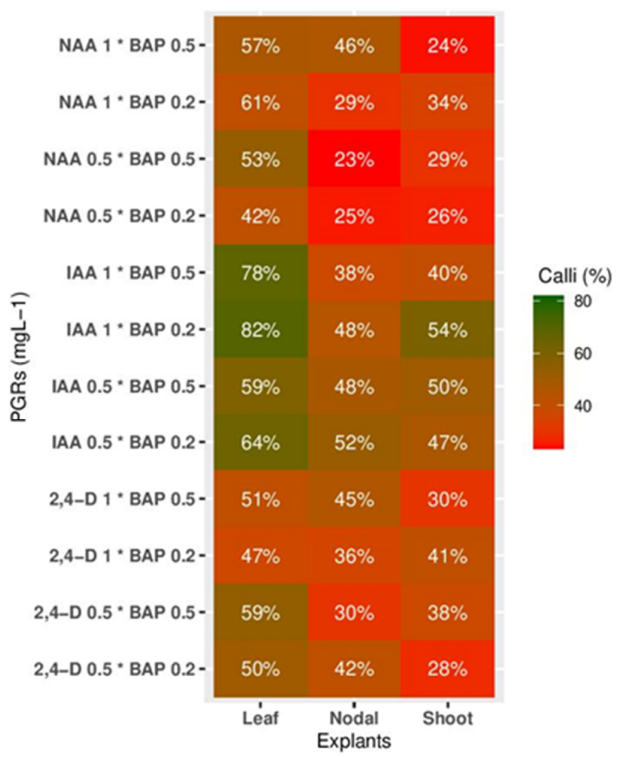

(a)

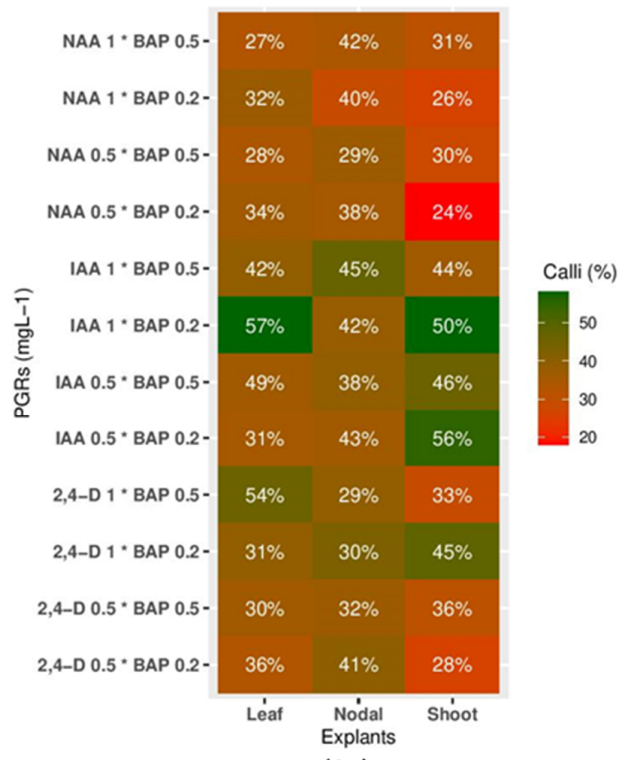

(b)

Figure 2. Callus induction frequency of Greater Celandine. (a) Callus induction rate using different plant growth regulators PGRs and explants on MS medium. (b) Callus induction rate using different PGRs and explants on B5 media. Each cell in the heatmap represents the mean value of six replicates. * represents the combination of PGRs. 


\subsection{Cell Growth}

Dry cell weight decreased remarkably as the elicitation time courses of elicitors increased (Figure 3). Significant effects were observed during different time courses in dry cell weight via elicitation of both elicitors in comparison with the controls. Both MJ and SA significantly decreased the dry cell weight at all elicitation time courses. Nonetheless, longer time elicitations, 48 and $72 \mathrm{~h}$, indicated more shrinkage in dry cell weight than shorter times, 12 and $24 \mathrm{~h}$. SA elicitation decreased dry cell weight from 40.13 to 32.23 and $30.07 \mathrm{~g} / 30 \mathrm{~mL}$ at 48 and $72 \mathrm{~h}$, respectively. In contrast to SA, MJ elicitation with 30.21 and $28.44 \mathrm{~g} / 30 \mathrm{~mL}$ at 48 and $72 \mathrm{~h}$ respectively, presented a higher influence in diminishing dry cell weight.

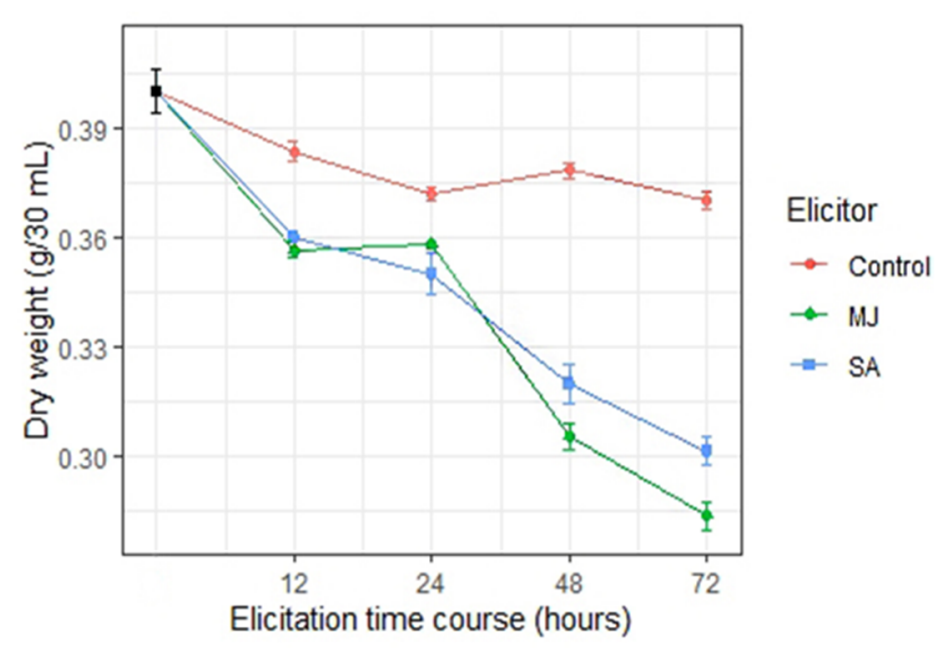

Figure 3. Effects of methyl jasmonate (MJ) and salicylic acid (SA) on cell growth of Greater Celandine at different time courses $(12,24,48$, and $72 \mathrm{~h}$ ). Dry weight of cells after 14 days of the culture cycle (stationary growth phase) is represented by the black point. Non-elicited cells were used as control. Each data represents the mean value of six replications and error bars represent mean \pm standard deviation (SD).

\subsection{Accumulation of BPAs}

The BPAs content of the treated and control cultures was measured after different times of elicitation. High-performance liquid chromatography (HPLC) uncovered significant improvements in the biosynthesis of BPAs under MJ and SA elicitations compared to control at almost all different time courses (Figure 4). The accumulation of chelidonine improved by 2.52 -fold $(5.61 \mu \mathrm{g} / \mathrm{mg})$ after $48 \mathrm{~h}$ of SA elicitation compared with the control (Figure 4a). A significant improvement was observed in the content of sanguinarine $(2.69 \mu \mathrm{g} / \mathrm{mg}$ ) after $72 \mathrm{~h}$ of SA elicitation (Figure $4 \mathrm{~b})$. The accumulation of berberine after $24 \mathrm{~h}$ of SA elicitation reached the maximum point of 4.89 -fold $(0.75 \mu \mathrm{g} / \mathrm{mg})$ in comparison with the control (Figure 4c). MJ-treated cells produced a higher level of chelidonine and sanguinarine compared to SA-treated ones (Figure $4 \mathrm{~d}, \mathrm{e}$ ). The amount of chelidonine after $72 \mathrm{~h}$ of MJ elicitation was considerably increased by 9.63 -fold $(9.86 \mu \mathrm{g} / \mathrm{mg})$ to its highest point (Figure $4 \mathrm{~d}$ ). After $24 \mathrm{~h}$ of MJ elicitation, the highest level of accumulation was observed in sanguinarine content by 13.22 -fold $(3.42 \mu \mathrm{g} / \mathrm{mg})$, in comparison with control (Figure 4e). 


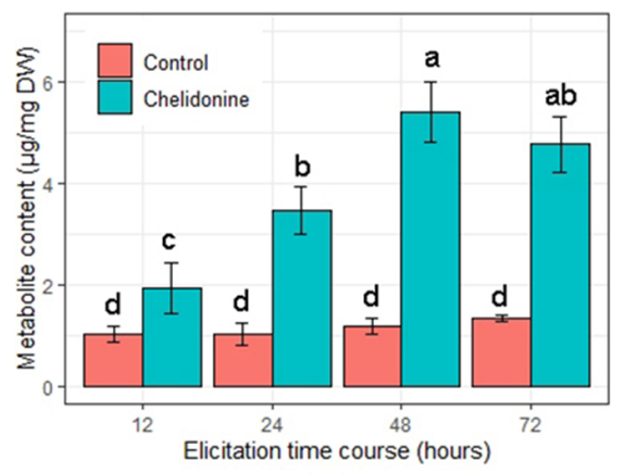

(a)

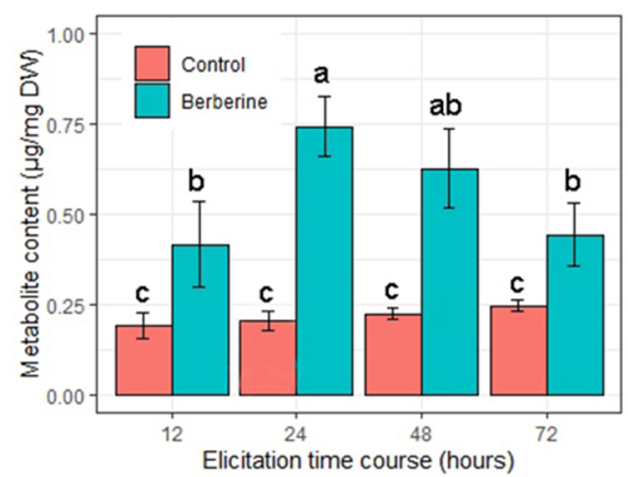

(c)

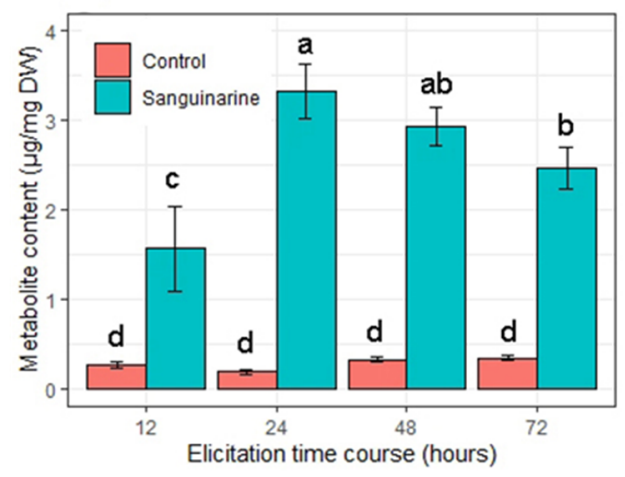

(e)

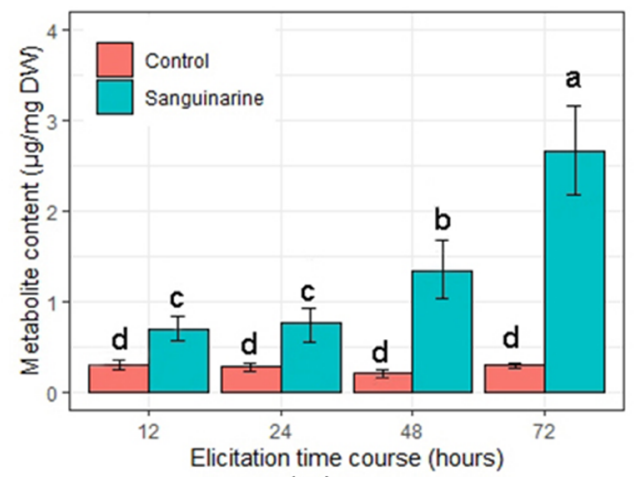

(b)

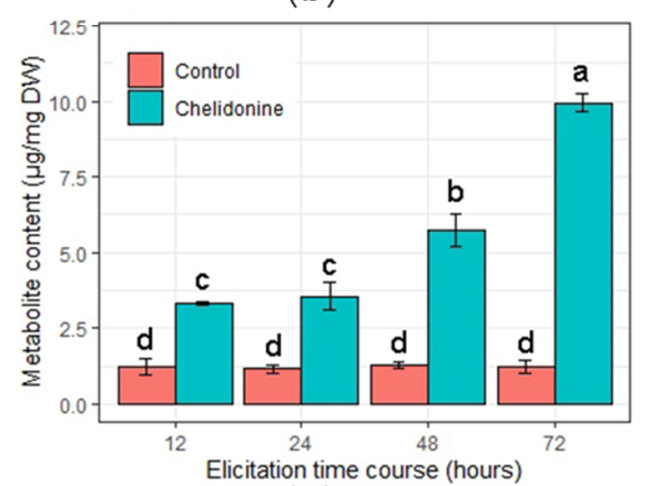

(d)

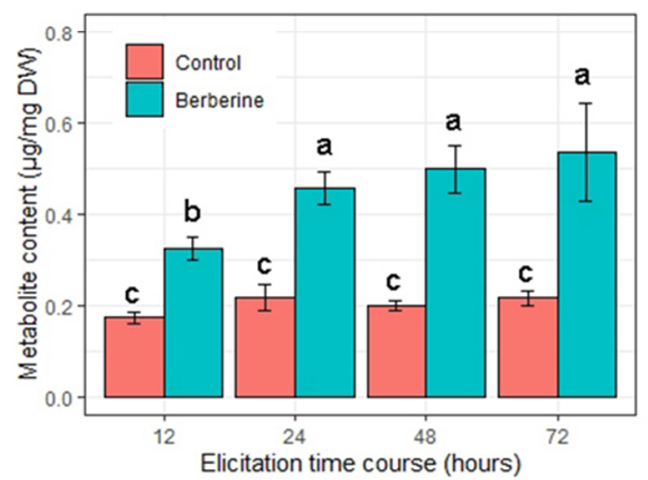

(f)

Figure 4. Effects of abiotic elicitors on the accumulation BPAs in cultured Greater Celandine cells. (a) chelidonine, (b) sanguinarine, and (c) berberine after elicitation by SA at 12, 24, 48, and $72 \mathrm{~h}$. (d) Chelidonine, (e) sanguinarine, and (f) berberine after elicitation by MJ at 12, 24, 48, and $72 \mathrm{~h}$. Non-elicited cells were used as control. Each column represents the mean value with the SD bar from three biological and three technical replicates. The significant difference is calculated by LSD (least significant difference) statistical analysis at the level of $p \leq 0.05$.

\subsection{Expression of BAPs Biosynthetic Genes}

To understand the mechanism of the BPAs production in cell suspension culture of Greater Celandine, expression level of key genes (CFS, STS, and TNMT) which are involved in BPAs biosynthesis was studied using quantitative real time polymerase chain reaction (qRT-PCR). Quantitative transcriptome analysis demonstrated that MJ and SA, at all the time courses, stimulated the transcription level of the genes in BPAs biosynthetic pathway. A notable association was detected between the expression level of candidate genes and the accumulation of BPAs. MJ has been noticeably effective on the upregulation of TNMT at 12, 24, and $48 \mathrm{~h}$ elicitation and enhanced the expression level of this gene by $2.79,4.75$, and 7.21 times respectively, in comparison with the control (Figure 5a). However, in comparison with 24 and $48 \mathrm{~h}$, a significant downregulation was observed 
in the expression level of TNMT at $72 \mathrm{~h} \mathrm{MJ} \mathrm{elicitation.} \mathrm{In} \mathrm{contrast} \mathrm{with} \mathrm{MJ,} \mathrm{a} \mathrm{significant}$ downregulation at $12 \mathrm{~h}$ and upregulation at $72 \mathrm{~h}$ was shown in the expression level of TNMT after SA elicitation. Improvement in the expression of STS was observed by MJ elicitation at any time course excluding $12 \mathrm{~h}$ and it reached the highest point at 6.17 times higher than the control after $72 \mathrm{~h}$ of elicitation (Figure $5 \mathrm{~b}$ ). In SA elicitation, an upregulation trend was observed in the expression of STS by increasing elicitation time courses, except for $12 \mathrm{~h}$. SA was also significantly effective on the downregulation of CFS at $24 \mathrm{~h}$ and decreased its expression level by 1.06 times compared to the control. However, MJ elicitation upregulated the transcription level of CFS by 2.62, 4.85, and 7.28 times higher than control at 12,24 , and $48 \mathrm{~h}$, respectively (Figure 5c). In general, longer time elicitations through MJ and SA could improve the expression level of key genes in the BPAs pathway.

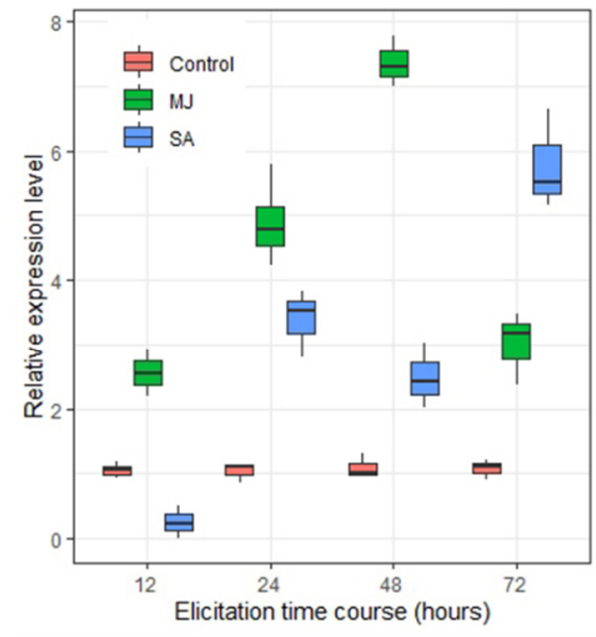

(a)

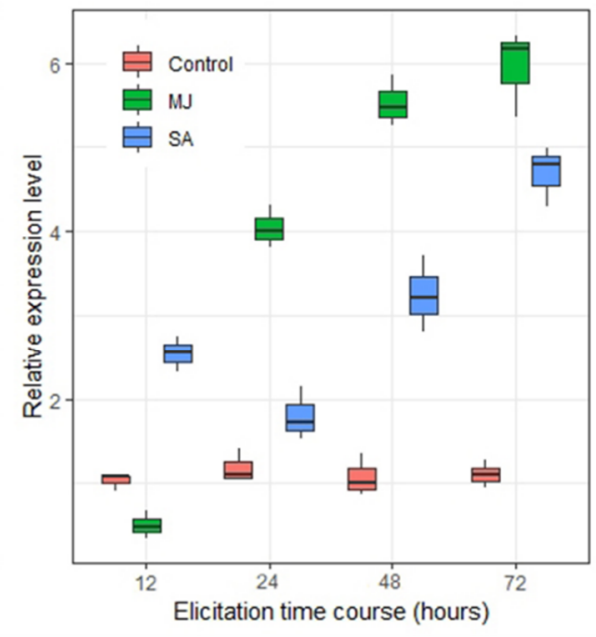

(b)

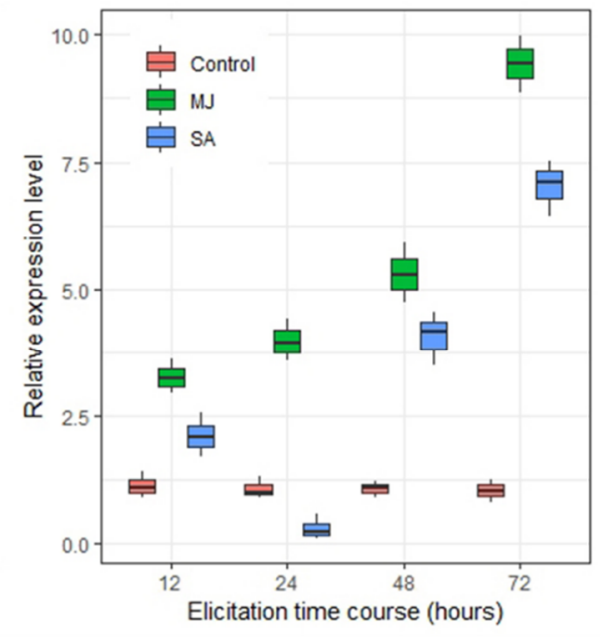

(c)

Figure 5. Effects of MJ and SA elicitation, at different time courses, on the expression of nominated benzophenanthridine alkaloids genes in cultured Greater Celandine cells. (a) TNMT, (b) STS, and (c) CFS. Non-elicited cells were used as control. The concentration of MJ and SA was $100 \mu \mathrm{M}$. EF1- $\alpha$ was used as an internal control to normalize variation in the amount of cDNA template. Each data point represents the mean value of three biological and three technical replications.

\section{Discussion}

In the present study, the discussion centers on improving the biosynthesis of plantderived pharmaceutically active components through biotechnologies. For quite a while, extraordinary efforts have been devoted to the investigation of the biosynthesis of plantderived bioactive components [21-23]. BPAs are of leading deliberation in traditional and modern pharmacology due to demonstrating pharmaceutically active features [19]. The high rate of cell growth and the good reproducibility of cells in suspension culture make it a suitable platform for the up-scale production of valuable SMs. The elicitation of cells in suspension culture is a more advanced strategy to improve the production of these highly valuable SMs [24]. Having an optimal callus growth platform would thus be a prerequisite to establishing cell suspension culture and further assessment of transcriptome and metabolome SMs [7].

Here, an appropriate cell growth platform was established to assess the expression and accumulation of BPAs in Greater Celandine. Two different media, MS and B5, were used to test callus initiation. MS and B5 media, due to their nutrition components, were previously documented as favorable media for callus induction of various medicinal plants, including Barringtonia racemosa L. and Allium chinensis G. Don. Our results disclosed that the MS medium is the most favorable for callus induction of Greater Celandine. Because of its higher concentration of nitrate, MS medium can improve cell growth and have a direct linkage with callus proliferation [25]. The type of explant is considered a vital factor in callus initiation as well [26]. Previous studies on in vitro proliferation of medicinal 
plants have described leaf explants as a suitable source for callus initiation and it is mainly due to the low level of SMs in leaves [26-28]. Leaf explants demonstrated the highest percentage of callus induction here as well. Eventually, among the PGRs, the combination of $1 \mathrm{mg} \mathrm{L}^{-1}$ IAA and $0.2 \mathrm{mg} \mathrm{L}^{-1}$ BAP were considerably more influential than others. It has already been reported that IAA, as a natural auxin, can induce higher callus formation than synthetic auxins $[29,30]$.

To conduct elicitation, cell suspension cultures were developed from calli. Cell suspension culture has proven to be a superior approach for improving SMs by elicitation in comparison with callus culture [24,31]. Two commonly used abiotic elicitors, MJ and SA, were found to be effective in triggering stress in cultured Greater Celandine cells. MJ and SA are involved in plant defense systems against stresses [32,33]. SA elicitation of Panax ginseng cells resulted in a reduction of cell weight by approximately $25 \%$ after nine days [34]. Furthermore, 9.25-fold L-Dopa content has been achieved in Hybanthus enneaspermus cultured cells with $150 \mu \mathrm{M}$ SA elicitor [35]. MJ has a similar effect as osmotic stress on plant cells [36]. Cell growth rate indicated that increasing the elicitation time course increased osmotic stress and resulted in cell degradation and decrement in cell growth accordingly. Another study on Taxus cells showed decreasing plant cell weight through elicitation as well [37]. Our findings indicated a significant reduction of cell weight through longer-term MJ-elicitation, suggesting that MJ treatment increases osmotic stress more than treatment with SA in longer elicitation times.

During the elicitation process, biosynthesis of SMs is controlled by various factors, such as elicitor specificity, elicitation exposure time, age of culture, etc. [38,39]. The application of exogenous MJ and SA have been well-recognized to stimulate the accumulation of SMs in plant cells. However, the effect of exogenous MJ and SA on the accumulation of BPAs in Greater Celandine cells has not been studied yet. Therefore, in the present study, both MJ and SA were identified as considerably effective abiotic elicitors in the biosynthesis of BPAs in Greater Celandine cells. MJ plays a fundamental role in inducing defense mechanisms that are biologically effective on the regulation of the signaling network leading to the biosynthesis of SMs $[40,41]$. Consequently, it was possible to observe MJ to serve as an effective elicitor in Greater Celandine cells by triggering the accumulation of BPAs as well as diminishing cell growth rate in comparison to the control.

A positive tendency of BPAs biosynthesis was also observed in SA-elicited cells but not in substantial quantities in comparison to MJ-elicited cells. Similar results have been observed in the cell suspension culture of Hypericum perforatum and Thevetia peruviana, and MJ improved biosynthesis of phenolic components when compared with SA elicitation [31,42]. Furthermore, in the elicitation approach, the duration of the elicitor exposure as well as the type of elicitor are two key factors that stimulate the biosynthesis of SMs [24]. Under both elicitor treatments, the greater production level of BPAs and lower cell growth rate were observed at longer time courses, indicating that longer time elicitations were more influential. Earlier studies reported SA and MJ as effective elicitors in improving the production of SMs at longer time courses [34]. However, biosynthesis of berberine and sanguinarine diminished by SA and MJ elicitation respectively, at 48 and $72 \mathrm{~h}$. It may be due to the lower activity level of TNMT enzyme or low expression level of TNMT gene at 48 and $72 \mathrm{~h}$ after MJ elicitation. Similar studies have documented that MJ and SA can activate and/or deactivate the expression level of associated genes with SMs in plant cells [43-45].

MJ and SA generally upregulated the expression of key genes CFS, STS, and TNMT, enhanced the accumulation of BAPs, and reduced cell growth rate. Such genes have already been well-described to play a leading role in the biosynthesis of BPAs [19]. The expression levels of CFS and STS were upregulated by longer elicitation times. However, TNMT was downregulated by MJ and SA at 72 and $48 \mathrm{~h}$, respectively. This variation in the expression of genes was found to be associated with the content of sanguinarine. It has already been reported that the biosynthesis of sanguinarine has a strong association with the expression level of CFS, STS, and TNMT [20]. CFS is the upstream enzyme of STS and TNMT in 
the benzophenanthridine alkaloids pathway [19]. Consequently, once the expression of CFS was upregulated by MJ at $72 \mathrm{~h}$, the content of chelidonine was enhanced, implying that the biosynthesis of chelidonine is associated with the expression level of CFS. Similar results were observed regarding the content of sanguinarine. Its content reduced when the expression of TNMT was downregulated, suggesting that this downregulation had an association with the accumulation of sanguinarine. Related findings have been welldocumented that SA improves the expression of isoquinoline alkaloids and the biosynthesis of related metabolites accordingly [20]. Nevertheless, SA has not been more effective in the production of chelidonine, which is most probably due to the expression levels of CFS. Since the content of alkaloids increased via increasing expression of related genes, it was detected that there might be a strong linkage between the gene's expression and the production of BPAs. Moreover, MJ and SA enhanced the content of chelidonine through the upregulation of CFS at all of the elicitation time courses. It has already been reported that upregulation of CFS can result in increasing the biosynthesis of chelidonine [46].

\section{Materials and Methods}

\subsection{Plant Materials and Seed Germination}

Seeds of Greater Celandine were obtained from the "Medicinal Herb Seed Bank (www.seedsnow.com) (accessed on 15 February 2015)". The seeds were surface-sterilized with $70 \%(v / v)$ ethanol for $1 \mathrm{~min}$ and $2.5 \%(v / v)$ sodium hypochlorite for $10 \mathrm{~min}$, then rinsed three times in sterile distilled water. Subsequently, the sterilized seeds were germinated on basal medium containing B5 salts and vitamins [47] with 3\% sucrose $(w / v)$ and solidified with $7 \%(w / v)$ agar. Finally, shoots, leaves, and nodals from forty-day-old plants were used as explants.

\subsection{Callus and Cell Suspension Culture}

Different explants including leaf, shoot, and nodal were placed on two different media-B5 and MS [48] - supplemented with 12 different combinations and concentrations of PGRs (IAA, BAP, NAA, and 2,4-D). In addition, each plate was supplemented with 3\% sucrose $(w / v), 0.5 \%$ ascorbic acid $(v / v), 0.5 \%$ polyvinylpyrrolidone $(w / v)$, and $7 \%$ agar $(w / v)$. The $\mathrm{pH}$ of the solutions was adjusted to 5.8 and then sterilized by autoclaving at $121^{\circ} \mathrm{C}$ for $20 \mathrm{~min}$. PGRs were filter-sterilized via $0.22 \mu \mathrm{m}$ cellulose acetate syringe filters and added to each base medium. To initiate calli, different explants were sub-cultured every 20 days and placed in a dark culture room at $22 \pm 0.5^{\circ} \mathrm{C}$ (Figure 1). Six replications were applied for each treatment.

For the development of cell suspension cultures, $1 \pm 0.05 \mathrm{~g}$ of calli were cultivated in $100 \mathrm{~mL}$ Erlenmeyer flasks containing $30 \mathrm{~mL}$ liquid medium, the same as callus culture media without agar and the same combination and concentration of PGRs (Figure 1c). The flasks were incubated in a rotary shaker $(110 \mathrm{rpm})$ at $22 \pm 0.5^{\circ} \mathrm{C}$ in dark conditions. Then, the cell suspension cultures were sub-cultured up to reaching homogeneity.

\subsection{Elicitation Treatments}

Elicitation treatment was carried out using MJ and SA (Sigma-Aldrich Co., Darmstadt, Germany) after 14 days (stationary growth phase) from the establishment of cell suspension culture. The stock solutions of MJ and SA were prepared in $99.9 \%$ ethanol. Subsequently, both solutions were sterilized by filtration $(0.22 \mu \mathrm{m}$ cellulose acetate syringe filters $)$ and added to the flasks. The final concentration of elicitors after adding to flasks, containing $30 \mathrm{~mL}$ liquid medium and $1 \pm 0.05 \mathrm{~g}$ of calli, was $100 \mu \mathrm{M}$. Afterwards, each flask was incubated at the same conditions for 12, 24, 48, and $72 \mathrm{~h}$. Filter-sterilized ethanol was added to the cell suspension culture as a control.

\subsection{Measurement of Cell Growth}

The cell growth was determined by measuring the dry cell weight after the 14th day of the culture cycle, stationary growth phase. Briefly, the separation of biomass from medium 
(each flask) was completed by filtration. Samples were washed several times by distilled water to eliminate the remaining medium from the cells. Later, via freeze drier, the biomass was lyophilized to obtain constant weight.

\subsection{Metabolite Extraction and Evaluation}

Freeze-dried cells, $50 \mathrm{mg}$ of each sample, were prepared with $1 \mathrm{~mL}$ of $99.9 \%$ methanol for $12 \mathrm{~h}$, followed by ultrasonic extraction (WiseClean ${ }^{\circledR}$ ) for $60 \mathrm{~min}$ at room temperature. The extract was centrifuged at $11,000 \times g$ for $8 \mathrm{~min}$. The supernatant was transferred to a new tube and dried at $55^{\circ} \mathrm{C}$. The residue was dissolved with $900 \mu \mathrm{L}$ of $\mathrm{HCl}$-methanol $25 \%$ hydrolyzed at $90{ }^{\circ} \mathrm{C}$ for $30 \mathrm{~min}$, and then brought to $1 \mathrm{~mL}$ using methanol [35].

To determine the content of BPAs, high-performance liquid chromatography (HPLC) (Knauer, PLATIN blue system, Berlin, Germany) was used. BPAs were identified through comparison of their retention time and absorption spectrum of their standard solution (Figure 6). A C18 column (Eurosphere, $250 \times 4.6 \mathrm{~mm}, 5 \mu \mathrm{m}$ ) with the mobile phase of $0.02 \mathrm{M} \mathrm{KH}_{2} \mathrm{PO}_{4}$-Acetonitrile $(95: 5 \mathrm{v} / \mathrm{v})$ was used as an analytical column. The flow rate was $1 \mathrm{mLmin}^{-1}$ with Ultraviolet (UV) detection wavelength at $280 \mathrm{~nm}$ and the column temperature was $25{ }^{\circ} \mathrm{C}$. To obtain a calibration curve, different concentration of standard solutions of BPAs (Sigma-Aldrich) were made via 99.9\% methanol (Sigma-Aldrich). Ultimately, the quantification of each BPA was determined via the calibration curves of standards. Three biological and three technical replications were applied in metabolome evaluation and the mean value of replications was used to display results.

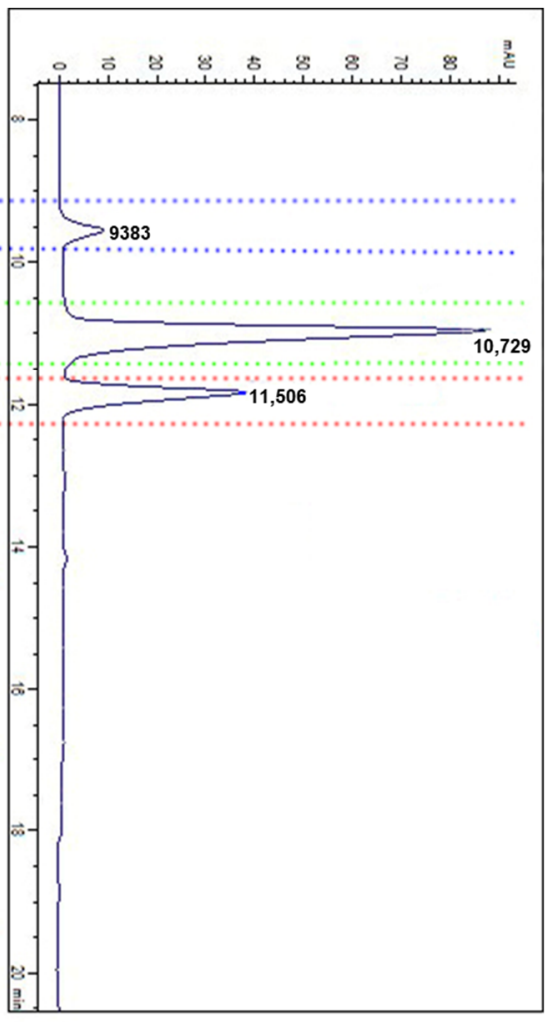

(a)

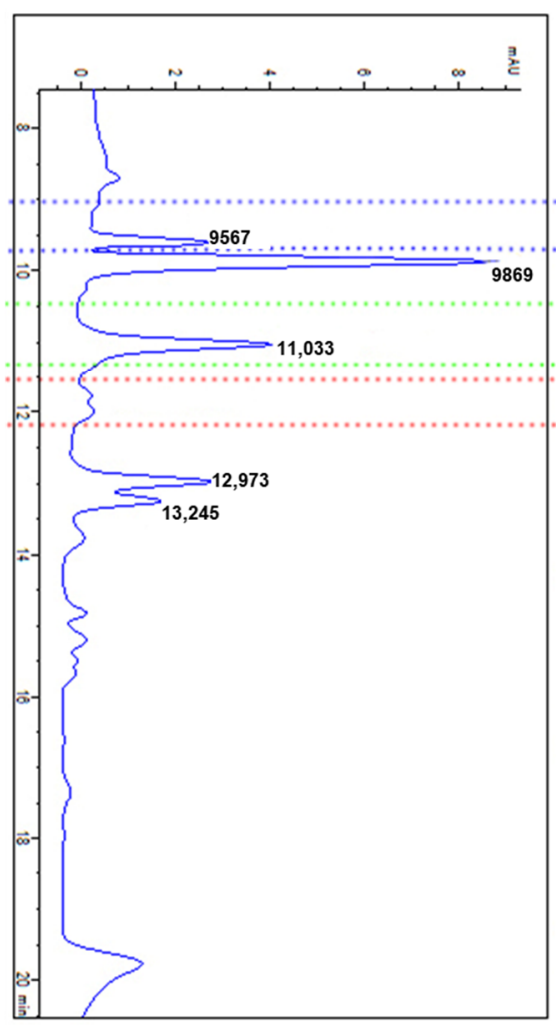

(b)

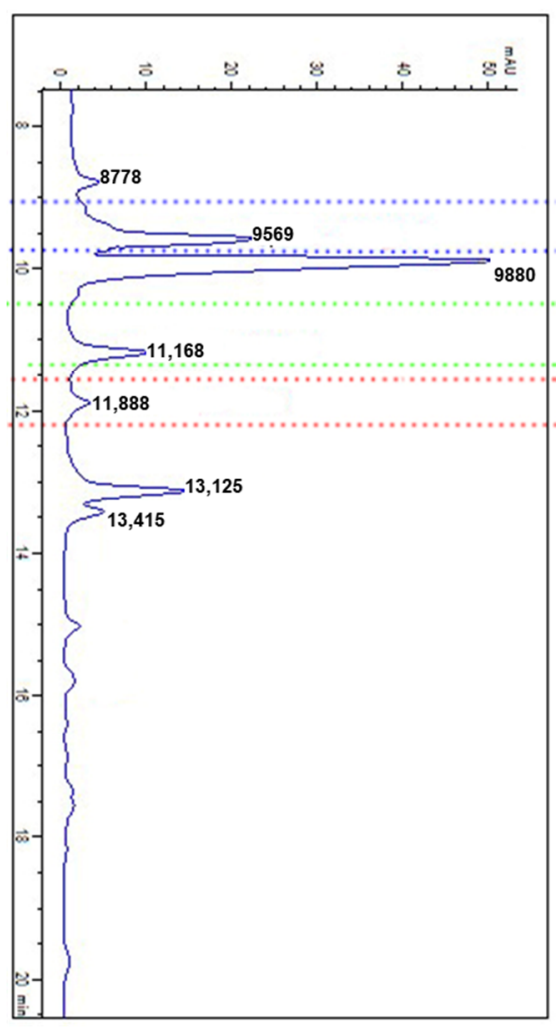

(c)

Figure 6. Retention time and absorption spectrum of BAPs and their external standards, as determined by high-performance liquid chromatography (HPLC). (a) HPLC chromatogram of the external standard of chelidonine, berberine, and sanguinarine, (b) HPLC chromatogram of the extract of cultured cells as a control sample, and (c) HPLC chromatogram of the cell extraction after $72 \mathrm{~h}$ of MJ elicitation. Retention time and peak shape of chelidonine, berberine, and sanguinarine are represented by blue, green, and red dotted lines, respectively. 


\subsection{RNA Extraction and Transcription Analysis}

Powered cells $(250 \mathrm{mg})$ with various elicitation treatments at the nominated time courses $(12,24,48$, and $72 \mathrm{~h}$ ) were collected for RNA extraction. The phenol-based method according to the manufacturer's instruction $\left(\mathrm{TRIzol}^{\circledR}\right)$ followed by subsequent treatment with DNase I (Thermo Fisher Scientific, Waltham, MA, USA) was used for the extraction of total RNA from the cells. Spectrophotometry (Nano-Drop, Technologies Inc., Waltham, MA, USA) and Qubit ${ }^{\circledR}$ (Thermo Fisher Scientific) were used to assess the quantity and quality of RNA. RNA integrity was evaluated from the $25 \mathrm{~S}$ and $18 \mathrm{~S}$ ribosomal RNA bands employing $1 \%$ non-denatured agarose gel electrophoresis. Later, $1 \mu \mathrm{g}$ of total extracted RNA was used to produce cDNA through the oligo (dT) 18 and random hexamer primer using the firststrand cDNA synthesis kit (Thermo Fisher Scientific). The primer sequences were designed on the foundation of the corresponding genes through Primer Quest software (http:// www.idtdna.com/pages/tools/primerquest) (accessed on 15 March 2016). The length of the target fragments, annealing temperature, and qRT-PCR condition are illustrated in Table 1. The reference gene was Elongation factor 1-alpha (EF1-a) (Table 1).

Table 1. Primers for target genes used for the quantitative real time polymerase chain reaction (qRT-PCR).

\begin{tabular}{cccc}
\hline Gene & Accession Number & Primer Sequence $\left(5^{\prime}-3^{\prime}\right)$ & Amplicon Length (bp) \\
\hline \multirow{2}{*}{ CFS } & GU325749.1 & F-GAAAAGGTCTTCAAGGTGTTGC & 150 \\
& R-GAGACGGTTCGATTACTAAGTCG & 187 \\
STS & GU325750.1 & F-TGGATCGGAAGTTGGAGAC & 107 \\
& R-GCCACATTTTGAAGACCTTTTCG & 113 \\
ENMT & EU882994.1 & F-GCAGTCGACGAGGATGACTGG & \multirow{2}{*}{ R-GTGCATTCCGTTCACAACCCAATGATC } \\
& XM026563191.1 & F-AGATGATTCCAACCAAGCCC & \\
\hline
\end{tabular}

Amplification assay was performed in a total reaction volume of $20 \mu \mathrm{L}$ containing $8 \mu \mathrm{L}$ Eva-Green Master Mix (containing Eva-Green Dye, Solis BioDyn, Düsseldorf, Germany), $1.5 \mu \mathrm{L}$ of amplified cDNA, $0.25 \mu \mathrm{M}$ of each primer, followed by adding PCR-grade water. The qRT-PCR was completed in the Rotor-Gene Q thermocycler (Qiagen Co., Hilden, Germany) as follows: 5 min pre-denaturation at $94{ }^{\circ} \mathrm{C}, 1$ cycle; 10 s denaturation at $94{ }^{\circ} \mathrm{C}$, $20 \mathrm{~s}$ annealing temperature, $15 \mathrm{~s}$ collection fluorescence at $72{ }^{\circ} \mathrm{C}, 35$ cycles. The gene expression quantification was carried out by the $2^{-\Delta \Delta C t}$ method [49]. In this means, the CT (the threshold cycle above which the boost in fluorescence is exponential) values of the target and control genes are standardized to an internal standard or reference. Besides, each data point represents the average of three biological and three technical replications.

\subsection{Statistical Analysis}

The experiment was carried out based on a factorial arrangement in a completely randomized design. All statistical analyses were performed using the $R$ agricolae package [50]. The data were analyzed by one-way analysis of variance (ANOVA) and all analytical values represent the averages of three biological and three technical replications. Visualization of data was accomplished using the R ggplot2 package [51]. The least significant difference (LSD) test at $p<0.05$ was used to calculate the difference between averages of the samples.

\section{Conclusions}

To design strategies to improve the production of bioactive compounds, an understanding of how plant cells at the transcriptome and metabolome levels respond to abiotic elicitors is a prerequisite. One of the main obstacles for the in vitro production of BPAs is the limited knowledge of biosynthetic pathways and their controlling enzymes and genes. Here, we addressed this challenge by testing two abiotic elicitors, MJ and SA, to establish their impact on transcription and accumulation of three key BAPs in Greater Celandine. Our results revealed that the accumulation of BPAs improved by the upregulation of can- 
didate genes, CFS, STS and TNMT, after MJ and SA elicitation. Our findings would be an advantage in bioengineering of the BPAs pathway and up-scale production of BPAs in Greater Celandine cell suspension culture.

Author Contributions: Conceptualization, S.M.H.; validation, E.B., M.G. and S.M.H.; formal analysis, S.M.H. and P.Z.; data curation and visualization, M.G. and C.P.; writing-review and editing, S.M.H., E.B.; C.P. and P.Z.; project administration, S.M.H. and M.R.N. All authors have read and agreed to the published version of the manuscript.

Funding: This research received no external funding.

Institutional Review Board Statement: Not applicable.

Informed Consent Statement: Not applicable.

Data Availability Statement: Not applicable.

Acknowledgments: The authors would like to acknowledge Kevin Gould and Oluf L. Gamborg for reviewing and editing the manuscript.

Conflicts of Interest: The authors declare no conflict of interest.

Sample Availability: Samples of the compounds are not available from the authors.

\section{References}

1. Funayama, S.; Cordell, G.A. Alkaloids: Treasury of Poisons and Medicines, 1st ed.; Academic Press: London, UK, 2014; ISBN 9780124173026.

2. Herrmann, R.; Roller, J.; Polednik, C.; Schmidt, M. Effect of chelidonine on growth, invasion, angiogenesis and gene expression in head and neck cancer cell lines. Oncol. Lett. 2018, 16, 3108-3116. [CrossRef]

3. Wang, X.; Feng, S.; Ding, N.; He, Y.; Li, C.; Li, M.; Ding, X.; Ding, H.; Li, J.; Wu, J.; et al. Anti-Inflammatory effects of berberine hydrochloride in an LPS-induced murine model of mastitis. Evid. Based Complement. Altern. Med. 2018, 2018, 1-9. [CrossRef]

4. Zielinska, S.; Wójciak-Kosior, M.; Dziagwa-Becker, M.; Glensk, M.; Sowa, I.; Fijałkowski, K.; Ruranska-Smutnicka, D.; Matkowski, A.; Junka, A. The activity of isoquinoline alkaloids and extracts from Chelidonium majus against pathogenic bacteria. Toxins 2019, 11, 406. [CrossRef] [PubMed]

5. El-Readi, M.Z.; Eid, S.; Ashour, M.L.; Tahrani, A.; Wink, M. Modulation of multidrug resistance in cancer cells by chelidonine and Chelidonium majus alkaloids. Phytomedicine 2013, 20, 282-294. [CrossRef] [PubMed]

6. Ernst, E.; Schmidt, K. Ukrain—a new cancer cure? A systematic review of randomised clinical trials. BMC Cancer 2005, 5, 69. [CrossRef] [PubMed]

7. Moscatiello, R.; Baldan, B.; Navazio, L. Plant Cell Suspension Cultures. In Methods in Molecular Biology; Springer: Cham, Switzerland, 2013; Volume 953, p. 297. ISBN 9781627031516.

8. Gabotti, D.; Locatelli, F.; Cusano, E.; Baldoni, E.; Genga, A.; Pucci, L.; Consonni, R.; Mattana, M. Cell suspensions of cannabis sativa (var. futura): Effect of elicitation on metabolite content and antioxidant activity. Molecules 2019, 24, 4056. [CrossRef]

9. Skalicky, M.; Kubes, J.; Hejnak, V.; Tumova, L.; Martinkova, J.; Martin, J.; Hnilickova, H. Isoflavones production and possible mechanism of their exudation in genista tinctoria L. suspension culture after treatment with vanadium compounds. Molecules 2018, 23, 1619. [CrossRef]

10. Akula, R.; Ravishankar, G.A. Influence of abiotic stress signals on secondary metabolites in plants. Plant Signal. Behav. 2011, 6, 1720-1731. [CrossRef] [PubMed]

11. Narayani, M.; Srivastava, S. Elicitation: A stimulation of stress in in vitro plant cell/tissue cultures for enhancement of secondary metabolite production. Phytochem. Rev. 2017, 16, 1227-1252. [CrossRef]

12. Yang, D.; Fang, Y.; Xia, P.; Zhang, X.; Liang, Z. Diverse responses of tanshinone biosynthesis to biotic and abiotic elicitors in hairy root cultures of Salvia miltiorrhiza and Salvia castanea Diels f. tomentosa. Gene 2018, 643, 61-67. [CrossRef]

13. Ochoa-Villarreal, M.; Howat, S.; Hong, S.; Jang, M.O.; Jin, Y.-W.; Lee, E.-K.; Loake, G.J. Plant cell culture strategies for the production of natural products. BMB Rep. 2016, 49, 149-158. [CrossRef] [PubMed]

14. Wasternack, C.; Strnad, M. Jasmonates: News on Occurrence, Biosynthesis, Metabolism and Action of an Ancient Group of Signaling Compounds. Int. J. Mol. Sci. 2018, 19, 2539. [CrossRef]

15. Gundlach, H.; Muller, M.J.; Kutchan, T.M.; Zenk, M.H. Jasmonic acid is a signal transducer in elicitor-induced plant cell cultures. Proc. Natl. Acad. Sci. USA 1992, 89, 2389-2393. [CrossRef] [PubMed]

16. Wiesel, L.; Davis, J.L.; Milne, L.; Fernandez, V.R.; Herold, M.B.; Williams, J.M.; Morris, J.; Hedley, P.E.; Harrower, B.; Newton, A.C.; et al. A transcriptional reference map of defence hormone responses in potato. Sci. Rep. 2015, 5, 15229. [CrossRef] [PubMed]

17. Kang, K.B.; Jayakodi, M.; Lee, Y.S.; Nguyen, V.B.; Park, H.; Koo, H.J.; Choi, I.Y.; Kim, D.H.; Chung, Y.J.; Ryu, B.; et al. Identification of candidate UDP-glycosyltransferases involved in protopanaxadiol-type ginsenoside biosynthesis in Panax ginseng. Sci. Rep. 2018, 8, 1-10. [CrossRef] 
18. Kutchan, T. Alkaloid Biosynthesis-The Basis for Metabolic Engineering of Medicinal Plants. Plant Cell 1995, 7, 1059-1070. [CrossRef]

19. Beaudoin, G.A.W.; Facchini, P.J. Benzylisoquinoline alkaloid biosynthesis in opium poppy. Planta 2014, 240, 19-32. [CrossRef]

20. Verma, P.; Khan, S.A.; Mathur, A.K.; Ghosh, S.; Shanker, K.; Kalra, A. Improved sanguinarine production via biotic and abiotic elicitations and precursor feeding in cell suspensions of latex-less variety of Papaver somniferum with their gene expression studies and upscaling in bioreactor. Protoplasma 2014, 251, 1359-1371. [CrossRef]

21. Atanasov, A.G.; Waltenberger, B.; Pferschy-wenzig, E.; Linder, T.; Wawrosch, C.; Uhrin, P.; Temml, V.; Wang, L.; Schwaiger, S.; Heiss, E.H.; et al. Discovery and resupply of pharmacologically active plant-derived natural products: A review. Biotechnol. Adv. 2015, 33, 1582-1614. [CrossRef] [PubMed]

22. Lee, K.-H. Anticancer drug design based on plant-derived natural products. Biomed. Sci. 1999, 7360, 236-250. [CrossRef]

23. Balandrin, M.F.; Klocke, J.A.; Wurtele, E.S.; Hugh, W. Natural plant chemicals: Sources of industrial and medicinal materials. Science 1985, 228, 1154-1160. [CrossRef]

24. Ramirez-estrada, K.; Vidal-limon, H.; Hidalgo, D.; Moyano, E.; Golenioswki, M.; Cusidó, R.M.; Palazon, J. Elicitation, an Effective Strategy for the Biotechnological Production of Bioactive High-Added Value Compounds in Plant Cell Factories. Molecules 2016, 21, 182. [CrossRef]

25. Kaczmarek, Z. The effects of genotype, inflorescence developmental stage and induction medium on callus induction and plant regeneration in two Miscanthus species. Plant Cell Tissue Organ Cult. 2010, 102, 79-86.

26. Farhadi, N.; Panahandeh, J.; Azar, A.M.; Salte, S.A. Effects of explant type, growth regulators and light intensity on callus induction and plant regeneration in four ecotypes of Persian shallot (Allium hirtifolium). Sci. Hortic. 2017, 218, 80-86. [CrossRef]

27. Ahmad, N.; Faisal, M.; Anis, M.; Aref, I.M. In vitro callus induction and plant regeneration from leaf explants of Ruta graveolens L. S. Afr. J. Bot. 2010, 76, 597-600. [CrossRef]

28. Kai, G.; Dai, L.; Mei, X.; Zheng, J.; Wang, W.; Lu, Y.; Qian, Z.; Zhou, G. In vitro plant regeneration from leaf explants of Ophiorrhiza japonica. Biol. Plant. 2008, 52, 557-560. [CrossRef]

29. Sitbon, F.; Sundberg, B.; Olsson, O.; Sandberg, G. Free and Conjugated Indoleacetic Acid ( IAA ) Contents in Transgenic Tobacco Plants Expressing the iaaM and iaaH IAA Biosynthesis Genes from Agrobacterium tumefaciens. Plant Physiol. 1991, 95, 480-485. [CrossRef]

30. Kumar, S.; Kumar, A.; Sahin, G.; Uslu, E. Influence of nutrient media on callus induction, somatic embryogenesis and plant regeneration in selected Turkish crocus species. Biotechnol. Rep. 2016, 10, 66-74.

31. Gadzovska, S.; Maury, S.; Delaunay, A.; Spasenoski, M.; Hagège, D.; Courtois, D.; Joseph, C. The influence of salicylic acid elicitation of shoots, callus, and cell suspension cultures on production of naphtodianthrones and phenylpropanoids in Hypericum perforatum L. Plant Cell Tissue Organ Cult. 2013, 113, 25-39. [CrossRef]

32. Siddiqi, K.S.; Husen, A. Plant response to jasmonates: Current developments and their role in changing environment. Bull. Natl. Res. Cent. 2019, 6, 153-164. [CrossRef]

33. Chronopoulou, L.; Livia, D.; Bramosanti, M.; Rosciani, R.; Palocci, C.; Pasqua, G.; Valletta, A. Microfluidic synthesis of methyl jasmonate-loaded PLGA nanocarriers as a new strategy to improve natural defenses in Vitis vinifera. Sci. Rep. 2019, 9, 1-9. [CrossRef]

34. Ali, M.B.; Yu, K.-W.; Hahn, E.-J.; Paek, K.-Y. Methyl jasmonate and salicylic acid elicitation induces ginsenosides accumulation, enzymatic and non-enzymatic antioxidant in suspension culture Panax ginseng roots in bioreactors. Plant Cell Rep. 2006, 25, 613-620. [CrossRef]

35. Sathish, S.; Vasudevan, V.; Karthik, S.; Pavan, G.; Manickavasagam, M. Enhanced l-Dopa production from elicited cell suspension culture of Hybanthus enneaspermus (L.) F. Muell. Plant Biotechnol. Rep. 2019, 13, 613-621. [CrossRef]

36. Chen, C.T.; Kao, C.H. Osmotic stress and water stress have opposite effects on putrescine and proline production in excised rice leaves. Plant Growth Regul. 1993, 13, 197-202. [CrossRef]

37. Patil, R.A.; Lenka, S.K.; Normanly, J.; Walker, E.L.; Roberts, S.C. Methyl Jasmonate Represses Growth and Affects Cell Cycle Progression in Cultured Taxus Cells. Plant Cell Rep. 2014, 33, 1479-1492. [CrossRef]

38. Siddaiah, C.N.; Satyanarayana, N.R.; Mudili, V. Elicitation of resistance and associated defense responses in Trichoderma hamatum induced protection against pearl millet downy mildew pathogen. Sci. Rep. 2017, 7, srep43991. [CrossRef]

39. Shi, M.; Zhou, W.; Zhang, J.; Huang, S.; Wang, H.; Kai, G. Methyl jasmonate induction of tanshinone biosynthesis in Salvia miltiorrhiza hairy roots is mediated by JASMONATE ZIM-DOMAIN repressor proteins. Sci. Rep. 2016, 6, 20919. [CrossRef]

40. Yu, X.; Zhang, W.; Zhang, Y.; Zhang, X.; Lang, D.; Zhang, X. The roles of methyl jasmonate to stress in plants. Funct. Plant Biol. 2019, 46, 197-212. [CrossRef]

41. Benevenuto, R.F.; Seldal, T.; Hegland, S.J.; Rodriguez-saona, C.; Kawash, J.; Polashock, J. Transcriptional profiling of methyl jasmonate-induced defense responses in bilberry (Vaccinium myrtillus L.). BMC Plant Biol. 2019, 19, 1-18. [CrossRef]

42. Mendoza, D.; Cuaspud, O.; Pablo, J.; Ruiz, O.; Arias, M. Effect of salicylic acid and methyl jasmonate in the production of phenolic compounds in plant cell suspension cultures of Thevetia peruviana. Biotechnol. Rep. 2018, 19, e00273. [CrossRef]

43. Cho, H.; Young, S.; Soon, H.; Yoon, S.H.; Lee-parsons, C.W.T.; Moon, J. Synergistic effects of sequential treatment with methyl jasmonate, salicylic acid and yeast extract on benzophenanthridine alkaloid accumulation and protein expression in Eschscholtzia californica suspension cultures. J. Biotechnol. 2008, 135, 117-122. [CrossRef] 
44. Xu, A.; Huang, J.Z.W. Effects of ultraviolet C, methyl jasmonate and salicylic acid, alone or in combination, on stilbene biosynthesis in cell suspension cultures of Vitis vinifera L. cv. Cabernet Sauvignon. Plant Cell. Tissue Organ Cult. 2015, 122, 197-211. [CrossRef]

45. Kumar, A.; Singh, R.S.; Kumar, U.; Rekha, K.; Thakur, D.; Pal, A.K.; Singh, P.K. Expression of MYB Transcription Factor Genes in Response to Methyl Jasmonate, Salicylic Acid and Sodium Nitropruside in Selaginella bryopteris (L.) Baker. Int. J. Agric. Environ. Biotechnol. 2018, 11, 30954.

46. Facchini, P.J. Alkaloid biosynthesis in plants: Biochemistry, cell biology, molecular regulation, and metabolic engineering applications. Annu. Rev. Plant Mol. Biol. 2001, 52, 29-66. [CrossRef] [PubMed]

47. Gamborg, L.; Miller, R.A.; OJIMAl, K. Nutrient requirements of suspension cultures of soybean root cells. Expr. Cell Res. 1968, 50, 151-158. [CrossRef]

48. Murasnige, T.; Folke, S. A revised medium for rapid growth and bio agsays with tobacco tissue cultures. Physiol. Plant. 1962, 15, 473-497. [CrossRef]

49. Schmittgen, T.D.; Livak, K.J. Analyzing real-time PCR data by the comparative CT method. Nat. Protoc. 2008, 3, 1101-1108. [CrossRef] [PubMed]

50. De Mendiburu, F.; Yaseen, M. Agricolae: Statistical Procedures for Agricultural Research. R Package Version 1.4.0. 2020. Available online: https: / / cran.r-project.org/package=agricolae (accessed on 24 October 2020).

51. Gómez-Rubio, V. ggplot2-Elegant Graphics for Data Analysis (2nd Edition). J. Stat. Softw. 2017, 77, 3-5. [CrossRef] 